\title{
PENGARUH KECEPATAN ALIRAN UDARA DENGAN PENGATURAN DIMMER PADA TEKANAN UDARA MASUK PADA PROSES GASIFIKASI SEKAM PADI TERHADAP PEMBENTUKAN FLAMABLE GAS
}

\author{
Suliono $^{1}$, Felix Dionisius ${ }^{2}$, Bambang Sudarmanta ${ }^{3}$ \\ 1,2Program Studi Teknik Mesin, Politeknik Negeri Indramayu. Jl. Lohbener Lama No.08, Indramayu \\ ${ }^{3}$ Jurusan Teknik Mesin FTI-ITS Kampus ITS Jalan Arief Rahman Hakim Keputih-Sukolilo Surabaya \\ ${ }^{1}$ Sulionolee@gmail.com, ${ }^{2}$ Dionisiusfelix@gmail.com ${ }_{2}^{3}$ sudarmanta@me.its.ac.id
}

\begin{abstract}
Abstrak
Proses gasifikasi biomassa merupakan cara untuk mendapatkan syn-gas yang mudah terbakar melalui pembakaran biomassa di dalam reaktor yang tertutup dengan bantuan udara dari blower tekan. Tanpa adanya bantuan udara proses pembentukan gas tidak mungkin terjadi, pada pembakaran didalam tungku harus ada udara yang dapat menyalakan api. Adapun alat untuk mensuplai udara adalah blower tekan. Tujuan penelitian ini adalah untuk mendapatkan campuran udara dan biomassa yang stoikiometri pada proses gasifikasi sekam padi. Dengan air fuel ratio (AFR) yang stoikiometri pada proses gasifikasi sekam padi akan menghasilkan syn-gas yang mudah terbakar secara sempurna.

Metode yang dilakukan dalam penelitian ini adalah mengubah zat padat sekam padi melalui proses gasifikasi. Gas yang dikeluarkan pada proses gasifikasi tersebut akan divariasikan pada kecepatan blower dengan menggunakan dimmer. Dari hasil pengujian tersebut dapat diketahui pada hasil keluaran syn-gas dari reaktor. pada dimmer 1 kecepatan udara masuk 3,5 m/s, pada dimmer 2 kecepatan udara 4,0 m/s. Pada dimmer 3 kecepatan udara $4,5 \mathrm{~m} / \mathrm{s}$ dan pada dimmer 4 kecepatn udara yang dihasilkan $5,0 \mathrm{~m} / \mathrm{s}$. Dari hasil pengujian kecepatan udara masingmasing variasi yang masuk kedalam reaktor hanya kecepatan udara $4,5 \mathrm{~m} / \mathrm{s}$ dan $5,0 \mathrm{~m} / \mathrm{s}$ atau pada dimmer 3 dan 4 yang dapat menghasilkan syn-gas yang mudah terbakar.
\end{abstract}

Kata Kunci: Gasifikasi, Dimmer, biomassa Sekam Padi, flame Syn-Gas

\begin{abstract}
The biomass gasification process is a way to obtain combustible syn-gas through combustion of biomass in a closed reactor with the help of air from a compressed blower. Without the help of air gas formation process is not possible, the combustion in the furnace must have air that can start a fire. The tool for supplying air is a pressure blower. The purpose of this study was to obtain a stoichiometric air and biomass mixture in the rice husk gasification process. With the stoichiometric air fuel ratio (AFR) in the rice husk gasification process, it will produce a perfect flammable syn-gas.

The method used in this research is to change the rice husk solid through the gasification process. The gas released in the gasification process will be varied at the blower speed with or without using a dimmer. From the test results, it can be seen in the syn-gas output from the reactor. on dimmer 1 the inlet airspeed is $3.5 \mathrm{~m} / \mathrm{s}$, on dimmer 2 the airspeed is $4.0 \mathrm{~m} / \mathrm{s}$. In dimmer 3 the air velocity is $4.5 \mathrm{~m} / \mathrm{s}$ and in dimmer 4 the air velocity produced is $5.0 \mathrm{~m} / \mathrm{s}$ From the results of testing the air velocity of each variation that enters the reactor only air velocity $4.5 \mathrm{~m} / \mathrm{s}$ and $5.0 \mathrm{~m} / \mathrm{s}$ or in dimmers 3 and 4 which can produce flammable syn-gas.
\end{abstract}

Keywords: Gasification, dimmer, Rice Husk Biomass, Syn-Gas flame 


\section{PENDAHULUAN}

Saat ini kebutuhan energi merupakan salah satu sumber kebutuhan utama manusia yang tidak dapat dipisahkan. Energi bisa berupa dari fosil dan tanaman yang dapat dimanfaatkan oleh manusia. Pada penelitian kali ini, peneliti berfokus kepada gasifikasi dari biomassa sekam padi. Sumber energi dari biomassa dapat diperbaharui sehingga energi biomassa merupakan energi yang terbarukan yang bisa diperbarui kembali. Teknologi konversi biomassa menjadi bahan bakar dapat dibedakan menjadi tiga yaitu pembakaran langsung, konversi termokimiawi dan konversi biokimiawi. Pada buku penelitian yang dilakukan (Abimanyu. $\mathrm{H}$ dan Hendrana. S, 2018) Teknologi gasifikasi biomassa merupakan suatu bentuk konversi energi yang terkandung di dalam biomassa. Proses gasifikasi berlangsung di dalam suatu reaktor yang disebut gasifier. Pada alat ini bahan bakar biomassa diurai di dalam reaktor (ruang bakar) dengan udara terbatas. Energi biomassa merupakan energi yang mudah didapat dengan cara melalui proses gasifikasi yang memanfaatkan panas pada tungku dengan bantuan udara dari luar. Blower tekan merupakan alat pensuplai udara agar pembakaran yang terjadi pada tungku tidak mati. Pada penelitian (Suhendi, E dkk 2016) yang meneliti pengaruh laju alir udara terhadap konsentrasi syn-gas yang Dihasilkan pada proses gasifikasi dibutuhkan suplai udara yang cukup tergantung pada massa bahan bakarnya, karena jika debit udara yang terlalu besar dapat memungkinkan jumlah gas hasil produksi akan mengandung banyak oksigen dan nitrogen yang berasal dari input udara. Semakin besar laju alir udara yang diberikan maka semakin tinggi konsentrasi syngas $\left(\mathrm{CO}, \mathrm{H}_{2}\right.$ dan $\left.\mathrm{CH}_{4}\right)$ yang dihasilkan. Namun dengan besarnya laju alir udara tidak sebanding dengan bahan bakar yang digunakan. Hal ini menyebabkan bahan bakar yang digunakan lebih cepat habis,sehingga profil konsentrasi syngas $\left(\mathrm{CO}, \mathrm{H}_{2}\right.$ dan $\left.\mathrm{CH}_{4}\right)$ yang dihasilkan cenderung menurun setiap waktunya. Penelitian yang dilakukan Najib, L. (2012) menyatakan bahwa kosentrasi kandungan synthetis gas pada gas mudah terbakar (combustible gas) cenderung mengalami penurunan dengan meningkatnya rasio udara-bahan bakar (Air Fuel Ratio). Hal ini dikarenakan peningkatan laju alir massa udara yang masuk melalui pengaturan dimmer pada blower yang akan meningkatkan rasio udara-bahan bakar (Air Fuel Ratio), akan tetapi kenaikan laju alir udara yang besar tidak sebanding dengan laju alir biomassa yang lebih kecil menyebabkan udara yang masuk kedalam reaktor gasifikasi ini berlebih, maka akan terbentuk banyak gas $\mathrm{O}_{2}, \mathrm{~N}_{2}, \mathrm{CO}_{2}$ dan combustible gas berkurang (gas $\mathrm{CO}, \mathrm{H}_{2}, \mathrm{CH}_{4}$ ).

\section{METODE}

Penelitian dilakukan secara eksperimental untuk mengetahui kualitas dan kuantitas syn-gas yang dihasilkan dari reaktor gasifikasi downdraft dengan bahan baku sekam padi serta perhitungan laju aliran udara pada reaktor gasifikasi yang telah dibuat. Adapun untuk mendapatkan sekam padi yang dipakai untuk penelitian sangat mudah karena daerah indramyau merupakan daerah penghasil padi. Pada penelitian ini bentuk reaktor gasifikasi akan dibuat untuk pengambilan data pada reaktor gasifikasi. Berikut bentuk gambar desain reaktor tersebut:

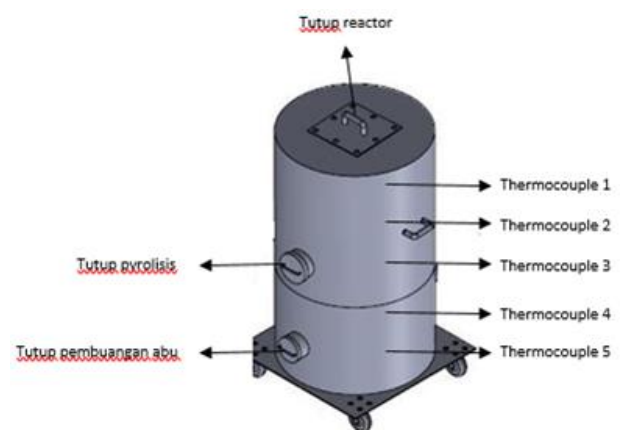

Gambar 1. Gasifikasi sekam padi

Gambar diatas mengindikasikan proses distribusi temperatur dari masing-masing zona pada downdraft gasifier ketika sedang dioperasikan. Pada fase drying atau pengeringan biomassa, reaksi yang terjadi adalah reaksi endoterm atau menghilangkan kandungan air dengan temperatur operasi kurang dari $300^{\circ} \mathrm{C}$. Pada fase pirolisis terjadi penguraian kandungan volatile (Kandungan dalam bomassa yang digunakan) dengan reaksi endoterm atau menyerap panas pada temperatur operasi berkisar $200^{\circ} \mathrm{C}-600^{\circ} \mathrm{C}$. Pada fase oksidasi parsial dimana pada fase inilah proses pembakaran biomassa terjadi dengan reaksi eksoterm atau menghasilkan panas pada temperatur operasi lebih dari $900^{\circ} \mathrm{C}$. Pada fase terakhir yaitu reduksi dimana fase ini akan mengurangi kandungan $\mathrm{CO} 2$ dengan temperatur operasi normal berkisar $400^{\circ} \mathrm{C}-900^{\circ} \mathrm{C}$. Dimana jika temperatur lebih rendah, akan menghasilkan nilai kalor yang terkandung pada gas hasil lebih rendah.

\subsection{Tahapan Proses Pengujian Gasifikasi Downdraft \\ 1. Drying}

Proses drying dilakukan untuk mengurangi kadar air (moisture) yang terkandung di dalam biomass 
bahkan sebisa mungkin kandungan air tersebut hilang. Temperatur pada zona ini berkisar antara $100-250^{\circ}$ C. Kadar air pada biomass dihilangkan melalui proses konveksi karena pada reaktor terjadi pemanasan dan udara yang bergerak memiliki humidity yang relatif rendah sehingga dapat mengeluarkan kandungan air biomass. Semakin tinggi temperatur pemanasan akan mampu mempercepat proses difusi dari kadar air yang terkandung di dalam biomass sehingga proses drying akan berlangsung lebih cepat. Reaksi oksidasi yang terjadi pada reaktor menghasilkan energi panas yang cukup besar dan menyebar ke seluruh bagian reaktor. Disamping itu kecepatan gerak media pengering turut mempengaruhi proses drying dengan persamaanya sebagai berikut: (wang, Ting \& Stiegel, 2017).

MainFeedstock + Heat $\rightarrow+H 2 \mathrm{O}$

\section{Pyrolisis}

Prolisis Pyrolisis adalah dekomposisi perubahan kimia dari biomassa menjadi berbagai produk yang bermanfaat, dalam keadaan tidak adanya oksidator secara total atau dengan pasokan yang terbatas yang tidak mengizinkan gasifikasi ke tingkat yang cukup. Ini adalah salah satu beberapa langkah reaksi atau zona diamati dalam gasifier. Selama pirolisis, molekul hidrokarbon kompleks biomassa terurai menjadi molekul yang lebih simple dan relatif lebih kecil seperti gas, cairan, dan char. Ini berlangsung pada suhu yang lebih besar dari $250-500^{\circ} \mathrm{C}$ dengan persamaan sebagai berikut ( Jayarama Reddy. P, 2016):

DryFeedstock + Heat $\rightarrow$ char + Volatiles

\section{Reduction}

Gasifikasi (reduction) ini adalah zona utama untuk mendapatkan syn-gas. Proses reduksi adalah reaksi penyerapan panas (endoterm), yang mana temperatur keluar dari gas yang dihasilkan harus diperhatikan. Pada proses ini terjadi beberapa reaksi kimia. Di antaranya adalah Bourdouar reaction, steam-carbon reaction, water-gas shift reaction, dan $\mathrm{CO}$ methanation yang merupakan proses penting terbentuknya senyawa - senyawa yang berguna untuk menghasilkan flammable gas, seperti hydrogen dan karbon monoksida. Proses ini terjadi pada kisaran temperatur $600^{\circ} \mathrm{C}$ sampai $1000^{\circ} \mathrm{C}$. Berikut adalah reaksi kimia yang terjadi pada zona tersebut (Mujiarto, S. et al., 2017):

Boudouard reaction

$C+O 2 \rightarrow 2 C O(-164.9 \mathrm{MJ} / \mathrm{kgmol})$
Steam-carbon reaction :

$\mathrm{C}+\mathrm{H} 2 \mathrm{O} \rightarrow \mathrm{CO}+2 \mathrm{H}(-122.6 \mathrm{MJ} / \mathrm{kgmol})$

water-gas shift reaction

$\mathrm{CO}+\mathrm{H} 2 \mathrm{O}=\mathrm{CO} 2+\mathrm{H} 2(+42,3 \mathrm{MJ} / \mathrm{kgmol})$

methanation

$\mathrm{C}+2 \mathrm{H} 2 \rightarrow \mathrm{CH} 4(+75 \mathrm{MJ} / \mathrm{kgmol})$

$\mathrm{CO}+3 \mathrm{H} 2 \rightarrow 4+\mathrm{H} 2 \mathrm{O}(-205.9 \mathrm{MJ} / \mathrm{kgmol})$

\section{Oksidasi parsial}

Oksidasi Parsial adalah proses yang menghasilkan panas (eksoterm) yang memanaskan lapisan karbon di bawah. Proses ini terjadi pada temperatur yang relatif tinggi, umumnya $700{ }^{\circ} \mathrm{C}$ $1500^{\circ} \mathrm{C}$. Pada temperatur setinggi ini pada gasifier downdraft, akan memecah substansi tar sehingga kandungan tar yang dihasilkan lebih rendah. Adapun reaksi kimia yang terjadi pada proses oksidasi ini adalah sebagai berikut (Anukam, A.I et al. 2017) :

$\mathrm{C}+\mathrm{O} 2 \rightarrow \mathrm{CO} 2(+393 \mathrm{MJ} / \mathrm{kgmole})$
$2 \mathrm{H} 2+\mathrm{O} 2 \rightarrow 2 \mathrm{H} 2 \mathrm{O}(+242 \mathrm{MJ} / \mathrm{kgmole})$

\section{Equivalence ratio $(\lambda)$}

Equivalence ratio $(\lambda)$ dalah parameter yang sangat penting pada pengoperasian reaktor gasifikasi. ER merupakan perban-dingan antara airfuel ratio (AFR) aktual pada pengoperasian reaktor gasifikasi dengan airfuel ratio (AFR) stoikio-metris adalah:

$$
\lambda=\mathrm{AFR}_{\mathrm{aktual}} / \mathrm{AFR}_{\text {stoikiometris }}
$$

AFR merupakan perbandingan antara jumlah udara dengan jumlah bahan bakar pada proses pembakaran. AFR stoikiometris adalah jumlah perbandingan udara dan bahan bakar yang menghasilkan pembakaran sempurna dapat dirumuskan, (Adrieq, A \& Sudarmanta, B 2016):

$$
\mathrm{AFR}=\text { Massa } \mathrm{udara} / \text { Massa bahan bakar }
$$

Kondisi stoikiometris teoritis biomassa diperoleh dengan mengetahui terlebih dahulu kandungan unsur kimia dari biomassa, kemudian dilakukan perhitungan persamaan reaksi yaitu reaksi oksidasi. Sehingga bila direaksikan dengan udara akan menjadi pembakaran sempurna sebagai berikut (Ardiansyah. I.M, 2017) :

$\mathrm{CH}_{1,4} \mathrm{O}_{0,6}+1,05 \mathrm{O}_{2} \rightarrow \mathrm{CO}_{2}+0,7 \mathrm{H}_{2} \mathrm{O}+\left(3,95 \mathrm{~N}_{2}\right)$

Nitrogen ditunjukkan dalam tanda kurung karena merupakan bagian yang tidak berubah (inert) dari udara dan tidak turut serta dalam reaksi dan tetap muncul pada hasil reaksi. Dari reaksi diatas dapat 
dilihat perbandingan antara udara dan biomassa untuk pembakaran sempurna adalah 10 berbanding $1($ AFR = 10) (Ardiansyah, I.M, 2017).

\section{HASIL DAN PEMBAHASAN}

Metode yang akan digunakan untuk penelitian ini adalah dengan cara membakar dengan suplai udara dari blower tekan yang dipasang dimmer sebagai pengatur keluaran udara yang masuk pada reaktor. Adapun pegujian pengambilan data akan dilakukan diworkshop polindra pada malam hari. Adapun pengujian pada malam hari untuk mengetahui syngas yang terbakar. Jika pengujian dilakukan disiang hari maka gas yang terbakar tidak kelihatan. Berikut alat uji untuk pengambilan syngas.

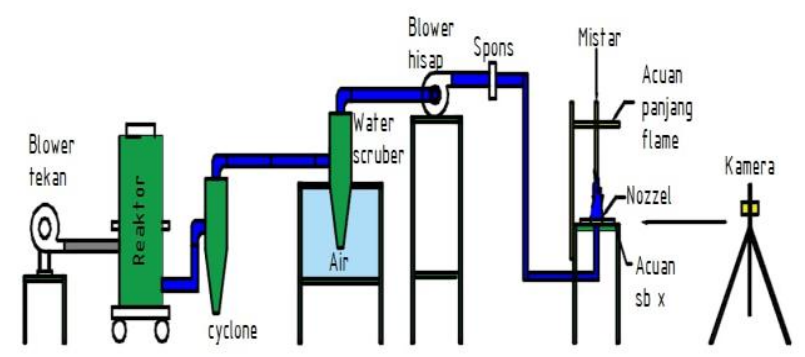

Gambar 2. Alat Pengujian

\section{Pipa pitot}

Pipa pitot digunakan untuk mengukur tekanan dan kecepatan aliran fluida di suatu titik. Pipa pitot merupakan pipa terbuka kecil dimana permukaannya bersentuhan langsung dengan aliran fluida. Pada penelitian ini menggunakan pitot static tube untuk mengukur kecepatan fluida udara yang masuk kedalam reaktor. Pitot static tube dihubungkan dengan manometer $\mathrm{U}$ untuk mengetahui besarnya mass flowrate yang masuk ke gasifier dengan menggunakan persamaan Bernoulli, berikut gambar konfigurasi pitot tube dan pipa masuk reaktor.

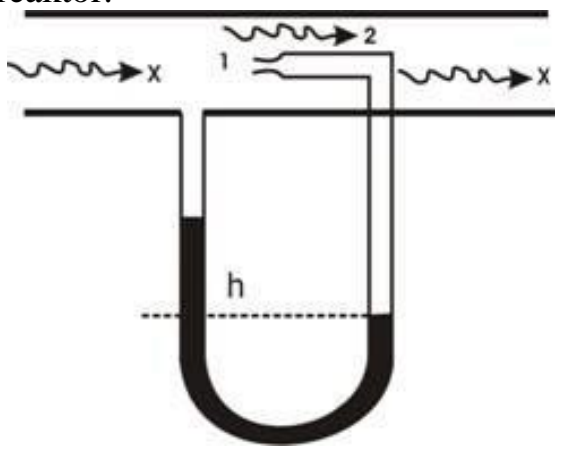

Gambar 3. Tabung/pipa pitot

Pitot static tube dihubungkan dengan manometer untuk mengetahui besarnya perbedaan ketinggian cairan pada manometer yang nantinya akan digunakan untuk mengetahui mass flow rate udara yang masuk ke ruang pipa dengan menggunakan persamaan bernoulli sebagai berikut:

$\mathrm{P}_{1}+\frac{1}{2} \rho v_{1}^{2}+\rho \mathrm{gh}_{1}=\mathrm{P}_{2}+\frac{1}{2} \rho v_{2}^{2}+\rho \mathrm{gh}_{2}$

Dimana:

$\mathrm{P} 1=$ Tekanan Statis $(\mathrm{Pa})$

$\mathrm{P} 2$ = Tekanan Stagnasi $(\mathrm{Pa})$

$\rho=$ Massa Jenis $\left(\mathrm{kg} / \mathrm{m}^{3}\right)$

$\mathrm{V}_{1}=$ Kecepatan Udara di Titi $1(\mathrm{~m} / \mathrm{s})$

$\mathrm{V}_{2}=$ Kecepatan Uadara di titk $2(\mathrm{~m} / \mathrm{s})$

Untuk mecari kecepatan udara yang masuk kedalam ruang reaktor dari persamaan diatas menjadi:

$\mathrm{V}=\sqrt{2 \frac{P_{o}-P}{\rho_{\text {udara }}}} \frac{m}{s}$

Dimana:

$$
\begin{aligned}
& \mathrm{P}_{\mathrm{o}}-\mathrm{P}=\rho_{\text {red oil }} \text {. g. } \mathrm{H} \\
& =\left(\rho_{\mathrm{H} 2 \mathrm{o}} \cdot \mathrm{SG}_{\text {red oil }}\right) \mathrm{g} \cdot \mathrm{h} \\
& \mathrm{H}=2 \mathrm{~L} \sin \theta \text { dan } \mathrm{L} \text { adalah perbedaan } \\
& \mathrm{V}=\sqrt{\frac{2 x \rho_{\mathrm{H} 2 \mathrm{O}} \times S G_{\text {red oil }} \times g \times 2 L \operatorname{Sin} \theta}{\rho_{\text {udara }}}} \frac{m}{\mathrm{~s}} \\
& \text { Dimana : } \\
& \mathrm{SG}_{\text {red oil }}=\text { Spesifik grafity red oil } \\
& \rho_{\mathrm{H} 20}=\text { massa jenis air } \\
& \rho_{\text {udara }}=\text { massa jenis udara } \\
& \mathrm{L} \quad=\text { selisih ketinggian cairan pada manometer } \\
& \Theta \quad=\text { besar sudut yang digunakan pada } \\
& \text { manometer } \mathrm{v}
\end{aligned}
$$

\section{Dimmer}

Dimmer berupa resistor yang digunakan untuk memvariasikan kecepatan suplai udara dari blower dengan cara membatasi arus listrik yang mengalir sehingga putaran blower bervariasi tergantung besar kecilnya angka dimmer. Dimmer digunakan untuk mendapakan nilai equivalence ratio yang diinginkan. Adapun dimmer yang digunakan dalam pengambilan data disetting mempunyai 5 tingkat kecepatan.

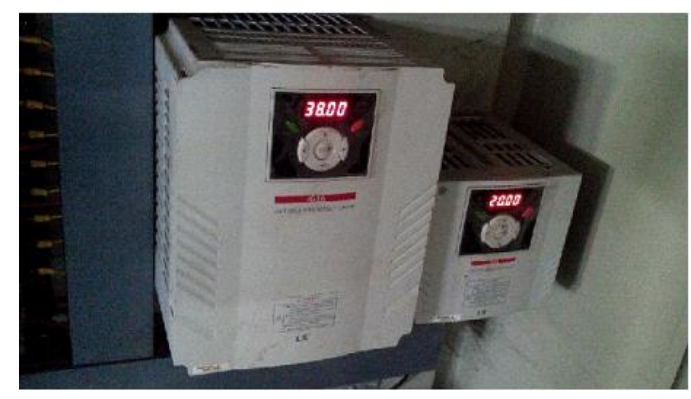

Gambar 4. Dimmer

Dari data yang didapat skema pengujian pada reaktor adalag data pengukuran temparatur yang dilakukan pada dinding reaktor gasifikasi. Dimana pengukuran reaktor tersebut menggunakan 
termokople pada masing masing fase, yaiti fase drying, pyrolisis, oksidasi parsial, reduksi, dan suhu gas. Dari termokople yang dipasang pada dinding reaktor akan di pasang menggunakan digital termokople untuk mengetahui suhu yang diukur oleh termokople.

\section{Pengukuran Temperatur Pada Reaktor}

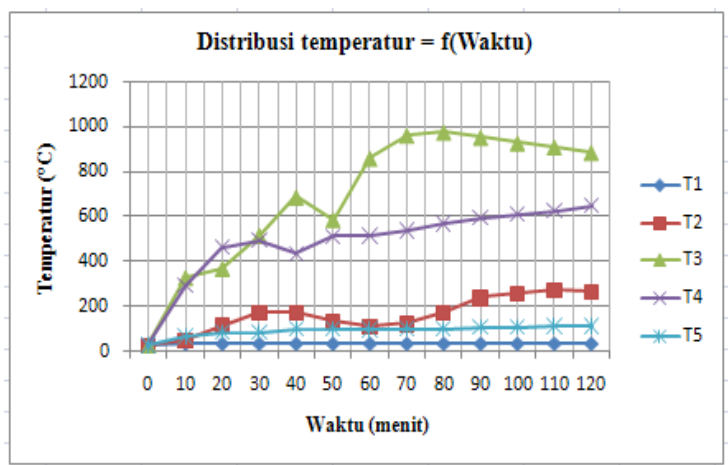

Gambar 5. Distribusi Temperatur

Dari hasil pengujian diatas pengukuran temperatur panas pada reaktor yang yang terendah pada thermocouple 1 sebesar $80^{\circ} \mathrm{C}$. Dimana pada fase ini adalah fase drying yaitu pengeringan biomassa sebelum dibakar. Pada thermocouple 2 menunjukkan fase pyrolysis, dimana proses ini adalah menghilangkan tar pada biomassa sekam padi dengan suhu panas yang ditunjukkan pada grafik $300^{\circ} \mathrm{C}$. Berikutnya adalah zona oksidasi parsial pada thermocouple 3 yaitu fase pembakaran biomassa pada tungku dengan suhu $990^{\circ} \mathrm{C}$. Pada proses ini akan diketahui AFR atau air fuel ratio antara biomassa yang dibakar dengan suplai udara yang diberikan. Dengan pengaturan dimmer maka blower tekan dapat diatur tekanan udara yang masuk ke tungku gasifikasi. Sehingga syn-gas yang keluar dari tungku dapat dibakar dengan baik atau tidak tergantung dari pengaturan dimmer. Pada thermocouple 4 ini adalah fase pelepasan syn-gas dari biomassa atau reduction, sehingga suhu pada zona ini suhu yang diukur mencapai $630^{\circ} \mathrm{C}$. suhu pada fase ini masih cukup tinggi karena masih berhubungan dengan zona oksidasi parsial. Dan pada fase yang terakhir adalah fase keluaran gas yang yang bercampur dengan $a s h / a b u$. Pada zona ini setelah diukur suhunya mencapai $110^{\circ} \mathrm{C}$. Dari setiap pengukuran yang menggunakan thermocouple pada masing-masing zona dapat diketahui sebaran suhu yang diberikan disetiap tingkatan. Temperatur tertinggi didapat pada posisi termocouple ke 3 di karenakan posisi tersebut tepat berada kondisi parcial oxidation yaitu proses terjadinya pembakaran. Hal ini sesuai dengan kondisi stoikiometri. dimana pembakaran sempuran antara pebandingan sekam padi dan udara akan terjadi bila reaktan tercampur sempurna pada tingkat molekul sebelum terjadinya reaksi kimia yang signifikan. Sehingga pada thermocouple T3 posisi di zona tersebut memiliki temperatur hingga $990^{\circ} \mathrm{C}$. Zona ini lebih tinggi bila dibanding pada posisi yang lain. Gambar pengujian dibawah ini merupakan visualisasi variasi pengaturan dimmer yang dilakukan saat pengujian.

\section{Visualisasi nyala api saat tekanan udara masuk} $3,5 \mathrm{~m} / \mathrm{s}$

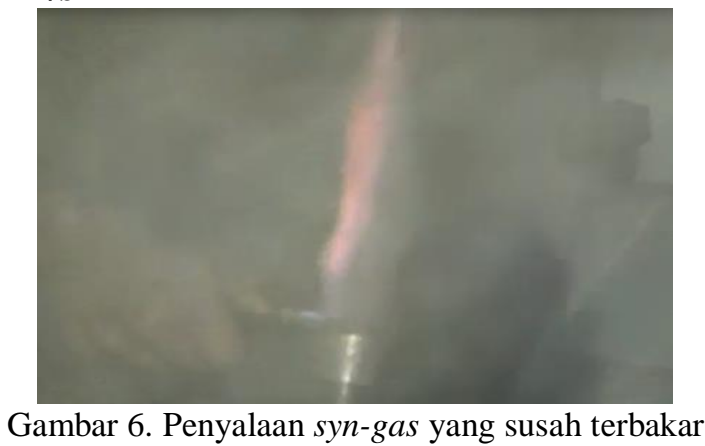

Dari hasil pengujian pembakaran nyala syn-gas dengan kecepatan udara $3,5 \mathrm{~m} / \mathrm{s}$ pada ujung burner masih belum bisa menyala dengan sempurna. Ini diakibatkan proses pencampuran udara dan bahan bakar didalam reaktor masih kurang sempurna atau masih terdapat perbedaan antara jumlah udara yang masuk dengan jumlah biomassa didalam tungku. Udara yang masuk kedalam tungku masih belum sebanding dengan jumlah biomassa sebanyak $10 \mathrm{~kg}$ yang ada didalam tungku untuk menjadikan gas yang flammable. Karena udara yang masuk tekanannya kecil sehingga syn-gas yang keluar dari tungku masih susah untuk dibakar. Perbandingan udara lebih sedikit dari bahan bakar biomassa mengakibatkan gas akan berubah menjadi asap dan akan susah terbakar dengan smpurna. Dari percobaan ini sangat jelas jika bahan bakar dengan massa $10 \mathrm{~kg}$ dengan diberikan udara dengan tekanan $3,5 \mathrm{~m} / \mathrm{s}$ akan sulit terbakar.

Pada pengujian pembakaran syn-gas dengan tekana udara $4,0 \mathrm{~m} / \mathrm{s}$ yang masuk kedalam reaktor dengan bahan bakar $10 \mathrm{~kg}$ sekam padi dilakukan setelah pengujian pertama dilakukan. Dalam pengujian pembakaran tersebut sudah terlihat bentuk nyala api yang kemerah-merahan yang keluar dari ujung burner akan tetapi masih sedikit sulit untuk terbakar dengan baik. Jika saat menyalakan syn-gas pemantik korek api harus nempel pada syn-gas. Dilihat bentuk warna nyala api dari perbandingan pertama dan kedua sudah terlihat perbedaaan karakteristik syn-gas. Tetapi pembakaran masih 
belum bisa terbakar sendiri karean syn-gas masih belum terbentuk dengan baik. Perbedaan asap yang keluar dari ujung burner sudah berkurang bila dibandingkan dengan pengujian yang pertama.

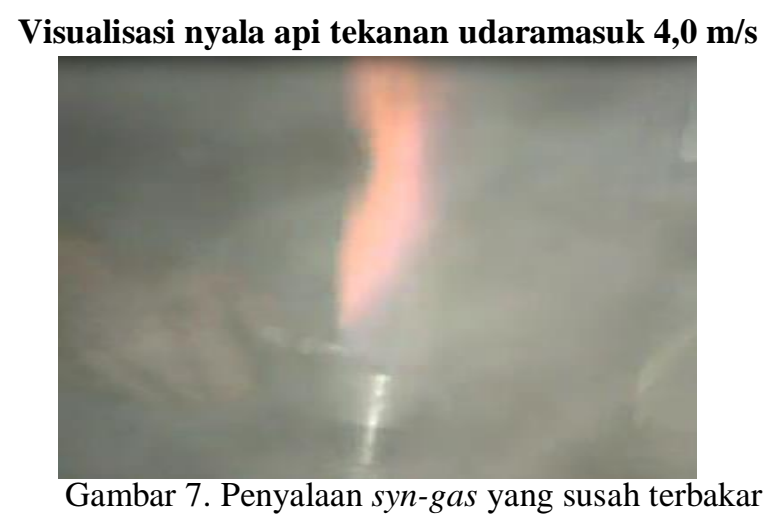

Visualisasi nyala api saat tekanan udara masuk 4,5 $\mathbf{m} / \mathbf{s}$

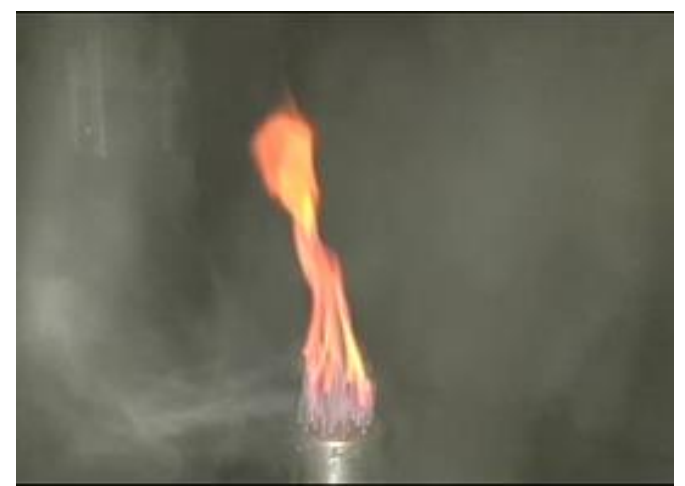

Gambar 8. Penyalaan syn-gas yang sudah bisa terbakar

Dilihat dari karakteristik nyala warna api syngas dengan kecepatan udara masuk kedalam reaktor sebesar $4,5 \mathrm{~m} / \mathrm{s}$ sudah bisa nyala sendiri akan tetapi masih pembakaran tidak seratus persen terbakar sempurna. Jika dilihat pada pangkal nyala syngas yang menempel pada burner tidak terbakar sempurna. Masih terlihat tidak terbakar semua pada pangkal ujung burner. Tetapi syngas yang keluar dari ujung burner sudah bisa terbakar dengan sendirinya. Untuk massa biomassa sekam padi sama seperti pada pengujian 1 dan 2 yaitu $10 \mathrm{~kg}$. Pada variasi ini perbandingan udara dan bahan bakar hampir sempurna jika dilihat dari visualisasi nyala syn-gas.

Dari hasil pengujian yang terakhir dengan kecepatan udara masuk kedalam reaktor sebesar 5,0 m/s dapat terlihat dengan baik apabila pemantik korek api didekatkan syn-gas yang keluar dari burner dapat nyala dengan sendirinya. Artinya perbandingan udara dan bahan bakar adalah perbandingan yang stoikiometri. Dari perbandingan tersebut akan dihasilkan gas yang sempurna. Terlihat pada gambar tidak ada asap yang bercampur dengan gas yang terbakar.

Visualisasi nyala api saat tekanan udara masuk 5,0 $\mathbf{m} / \mathbf{s}$

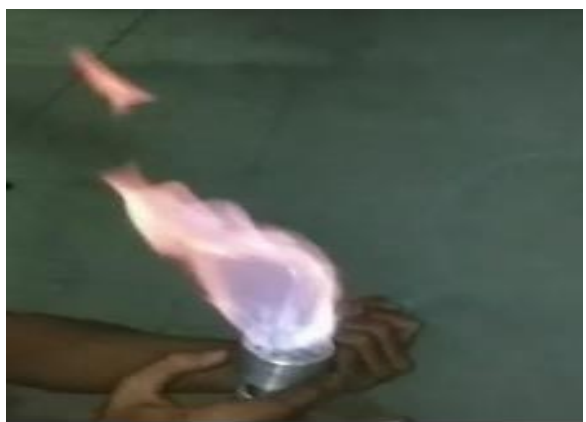

Gambar 9. Penyalaan syn-gas yang terbakar sempurna

\section{PENUTUP}

\section{Kesimpulan}

Dari hasil pengujian ini dapat ditarik kesimpulan berupa:

1. Dalam proses gasfikasi yang memvariasikan udara pada blower yang diatur oleh dimmer yang masuk kedalam reaktor dapat terlihat dari hasil pengujian visualisasi nyala syn-gas dari yang susah terbakar hingga syn-gas yang mudah terbakar serta campuran udara dan biomassa yang stoikiometri dari masingmasing variasi.

2. Dari beberapa variasi kecepatan udara pada blower yang masuk ke reaktor dengan pengaturan dimmer yang sudah diuji coba untuk nyala api syn-gas yang paling baik saat diberi pemantik korek api adalah variasi dengan kecepatan udara $5,0 \mathrm{~m} / \mathrm{s}$

\section{Saran}

Saran untuk penelitian ini adalah masih terdapat kebocoran pada reaktor yang mengakibatkan gas terbuang ke udara bebas yang mengakibatkan gas akan cepat habis.

\section{Ucapan Terima Kasih}

Artikel ini merupakan bagian dari kegiatan riset yang didanai oleh DIKTI melalui LPPM Politeknik Negeri Indramayu tahun anggaran 2019, untuk itu pada kesempatan ini penulis mengucapkan terima kasih kepada Dirjen DIKTI dan LPPM Politeknik Negeri Indramayu atas pendanaan yang telah diberikan. 


\section{DAFTAR PUSTAKA}

Abimanyu, H \& Hendrana, S. (2018). Konversi biomassa untuk energy alternative di Indonesia: tinjauan sumber daya, teknologi, manajemen dan kebijakan. Jakarta: LIPPI Press.<

https://www.researchgate.net/publication/32 5284362>

Suhendi, E. (2016). Pengaruh Laju Alir Udara dan

Waktu Proses Gasifikasi Terhadap Gas Producer Limbah Tangkai Daun Tembakau Menggunakan Gasifier Tipe Downdraft. Jurnal Bahan Alam Terbarukan.

$<$ https://journal.unnes.ac.id/nju/index.php/jb at/article/view/6054/5624>

Najib, L., Darsopuspito, S. (2012). Karakterisasi Proses Gasifikasi Biomassa Tempurung Kelapa Sistem Downdraft Kontinyu dengan Variasi Perbandingan Udara-Bahan Bakar (AFR) dan Ukuran Biomassa, Jurnal Teknik ITS, Vol. 1, No. 1. $<$ http://ejurnal.its.ac.id/index.php/teknik/arti cle/view/1837>

Wang, Ting \& Stiegel, G. (2016). Handbook of intergrated gasification combined cycle $(I G C C)$ technologies. Energy Conversion and Conservation Center, University of New Orleans,

USA. $<$ https://www.elsevier.com/books/integ rated-gasification-combined-cycle-igcctechnologies/wang/978-0-08-100167-7>

Jayarama Reddy, P. ( 2016). Energy Recovery From Municipal Solid Waste by Thermal Conversion Technologies. ISBN: 978-1-138029552 (Hbk). ISBN: 978-1-4987-7704-9 (eBook).

https://www.routledge.com/Energy-

Recovery-from-Municipal-Solid-Waste-by-

Thermal-Conversion-

Technologies/Reddy/p/book/9781138612112 $>$

Mujiarto, S., Suliono., Maolana, I., Murdjani. ( 2017). Karakteristik Gas Buang Dual Fuel Gasifier Downdraft Serbuk Kayu Dan Diesel Engine Generator Set $3 \mathrm{KW}$. Jurnal INTEKNA, Volume 17, No. 2, 79-147. < http://ejurnal.poliban.ac.id/index.php/intekna larticle/view/477 >

Anukam, A.I., Goso, Boniswa P., Okoh, Omobola O., Mamphweli, Sampson N. (2017). Studies On Characterization of corn Cob For Aplication In a Gasification Process For Energy Production. Journal Of chemistry.
Article ID 6478389, 9 Pages < https://doi.org/10.1155/2017/6478389>

Adrieq, A \& Sudarmanta, B. (2016). Studi Eksperimental Pengaruh Air Fuel Ratio Proses Gasifikasi Briket Municipa Solid Waste Terhadap Unjuk Kerja Gasifier Tipe Downdraft. JURNAL TEKNIK ITS Vol. 1, No. $1, \quad$ (2016) ISSN: <https://www.researchgate.net/publication/3 $\underline{16241837>}$

Ardiansyah, I.M. (2017). Studi Eksperimental Pengaruh Air Fuel Ratio (AFR) Proses Gasifikasi Pellet Municipal Solid Waste (MSW) Terhadap Unjuk Kerja Gasifier Tipe Downdraft Sistem Kontinyu. Tugas Akhir ITS Surabaya. < http://repository.its.ac.id/45800/1/211510503 3\%20-\%20Undergraduate_Thesis.pdf> 